Vol. 2, No. 2, December 2021

\title{
SPEKTA
}

Jurnal Pengabdian Kepada Masyarakat : Teknologi dan Aplikasi

Journal homepage :

http://journal2.uad.ac.id/index.php/spekta

\section{IMPLEMENTATION OF HEALTH-BASED STANDARD OPERATING PROCEDURES (SOP) AS COVID-19 MITIGATION IN HOTEL INDUSTRY}

Anita Wijayanti *, Kartika Hendra Titisari , Purnama Siddi, Riana R Dewi

Department of Accounting, Universitas Islam Batik, Indonesia

\section{ARTICLE INFO}

Received : December, 2020

Revised : May, 2021

Accepted : May, 2021

Keywords:

SOP;

mitigation;

prevention;

document.

\begin{abstract}
In Indonesia, the Covid-19 virus has infected since March 2, 2020. Since then, the Large-Scale Social Restrictions (PSBB) policy has been implemented in several areas with a high spread of the virus, (Regulation of the Minister of Health of the Republic of Indonesia No. 9 of 2020). This is used to suppress the spread of the virus. Hospitality is one of the tourism industries affected. The problem of hotel occupancy rates has decreased due to the Covid 19 pandemic in hotels, forcing a number of hotels to experience temporary or permanent closures. In an effort to develop standard governance standards in mitigating the impact of the Covid 19 outbreak for the hotel industry, the community service team views the need to establish standard operating procedures (SOPS) to prevent and control the impact of Covid 19 in the hotel industry. The object of this activity is the management of Hotel Laweyan Surakarta. The methods used were socialization, FGD and trials. At this stage the output produced is SOP Front Office and Housekeeping. The PKM team also helped with a set of tools for washing hands and personal protective equipment. SOPs are important especially for disaster mitigation and health services to control the stages of activities so that they are easy to monitor.
\end{abstract}

\section{INTRODUCTION}

World Health Organization (WHO) had previously explained that Corona Virus (Covid-19) is a virus that attacks the respiratory system started from mild respiratory infections such as flu to severe ones such as Severe Acute Respiratory Syndrome (SARS). It then automatically causes Middle-East Respiratory Syndrome (MERS) (Budiyono, 2020). This virus was first discovered in Wuhan City, China at the end of December 2019. The symptoms of this disease are high fever, cough, and shortness of

\footnotetext{
* Corresponding author.

E-mail address: rianardewi1@gmail.com

https://doi.org/10.12928/J.spekta.v2i2.3279
} 
Vol. 2, No. 2, December 2021

breath (Ministry of Health of the Republic of Indonesia, 2020). Due to the spread of this virus, many countries have implemented various strategies. Among those several selected strategies, lockdown system is currently being implemented in various countries such as China, Italy, and Spain (Aida, 2020).

In Indonesia, the Covid-19 virus has been infecting since March 2, 2020. Furthermore, an overview of the spread of Covid-19 to date can be seen through the following graph as cited from the Ministry of Health of the Republic of Indonesia.

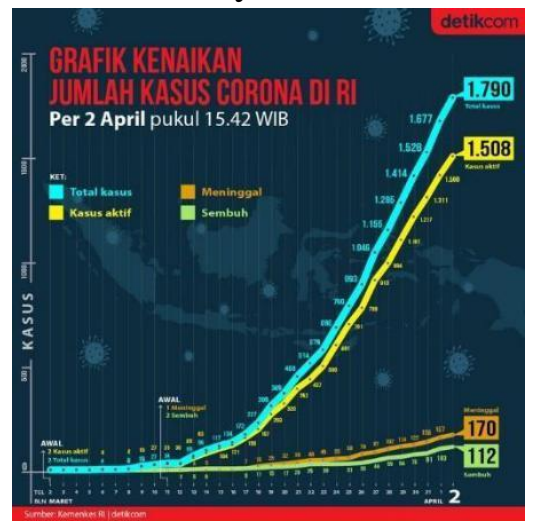

Figure 1. Covid-19 Outbreak Graph in Indonesia.

Starting from mid-March 2020, a Large-Scale Social Restriction (PSBB) become the preferred policy implemented due to stop the increasing number of Covid-19 sufferers. PSBB is executed in several areas with high levels of virus spread such as Jakarta, Depok, and Surabaya (Regulation of the Minister of Health of the Republic of Indonesia No. 9 of 2020). This is used to suppress the spread of the virus. Indeed, the government has implemented a KLB (Extraordinary Events) strategy in some certain cities so that people are required to limit their activities. In Surakarta, Covid-19 cases began to appear in April as many as 10 cases based on data from the Health Service. The number of migrants working in Surakarta is one of the causes of the increasing number of Covid-19 in Surakarta. Therefore, the Surakarta City Government finally determined an Extraordinary Event (KLB). The City Government issues regulations to the public to always keep their distance, maintain health protocols, stay at home. If they have to leave the house, they must wear masks and provide hand sanitizers (Kiswantoro, Rohman, and Susanto, 2020) and have a good and healthy lifestyle (Lina Dewi Anggraeni, 2020).

As the impact of the Covid 19 Pandemic, the Indonesian government's together with some other countries had implemented some similar regulations related to intercountry travel. Besides, they also put pressure on the tourism industry, which was very visible in the large decline in foreign tourist arrivals with massive cancellations and a decrease in bookings for visits (Buana, 2017).. The decline also occurred due to a slowdown in domestic travel, the reluctance of Indonesians to travel, and the concern about the impact of Covid-19. Surakarta is one of the cities of cultural and culinary tourism where many Hospitality and Culinary Centers are found in almost all corners of this city.

The Central Statistics Agency (BPS) of Surakarta noted that during the corona pandemic, especially in March, the room occupancy rate (TPK) for star hotels in Solo was 31.09 percent. This figure decreased by 23.05 points compared to the TPK in February 2020 of 54.14 percent. The average length of stay (RLM) for all-star hotel 


\section{Vol. 2, No. 2, December 2021}

guests in March 2020 was recorded at 1.50 days. It increases by 0.09 points compared to February 2020 of 1.41 days (Totok Tavirijanto, 2020). Hospitality is one of the tourism industries that has been affected. The problem of declining hotel occupancy rates due to the Covid-19 pandemic in hotels forces several hotels to experience closure, either temporarily or permanently. Available hotels during the Covid-19 pandemic are also experiencing serious problems such as fewer governance standards for planning, implementing, and controlling the impact of outbreaks/disasters for the hospitality industry. Considering those involved in the hospitality industry business chain is very complex. This is important to be fixed and is a serious concern so that future epidemic/disaster mitigation can be handled better with more clearly defined steps (Fitri, Nurcandra, and Pristya, 2020).

Standard Operating Procedure (SOP) is a system that is structured to facilitate, clarify the stages and make work orderly. This system contains a sequence of processes for doing work from start to finish (Fitri, Nurcandra, and Pristya, 2020). This system contains a sequence of processes for doing work from start to finish (Fitri, Nurcandra, and Pristya, 2020). SOP is used as a tool to measure the performance of employees and management towards compliance with its implementation. In the SOP there are also indicators to measure the level of success in compliance (Junita, 2017). SOP is used as a foothold defined (Buchori, 2019). Every company action, regardless of form and type, requires a guide to carry out the duties and functions of each element or unit of the company (Windu, 2017). Nevertheless, SOPs are still considered less important, especially in Hospitality for the category of medium class hotels.

As an effort to develop governance standards in mitigating the impact of the Covid-19 outbreak on the hotel industry, the community service team sees the need for a Standard Operating Procedure (SOP) to prevent and control the impact of COVID-19 in the hospitality industry. The community service team in collaboration with the Indonesian Hotel and Restaurant Association (PHRI) in Surakarta and also the Laweyan Hotel arranged and compiled SOPs in the context of mitigating the Covid-19 pandemic outbreak. Impacts from the mitigation will also appear following the performance outcomes (Kurniawan and Jayanti, 2016).

\section{METHOD}

This community service was implemented through several stages as explained below:

1. Socializing and introducing the programs

This stage explains the hotel's understanding of the importance of mitigating the Covid-19 disaster. This was done through socialization about Covid-19 to hotel management and employees. The community service team carried out this introduction in collaboration with health workers to disseminate information to hotel management. A number of employees (7 employees) were trained on healthy living behavior during the Covid 19 pandemic. This introductory stage was done to get the preliminary data related to the Covid-19 pandemic as well as the way to prevent it (Pinontoan, Dengo, and Ruru, 2015). A prominent understanding of covid-19 needs to be given in its entirety because of the vast danger and impact on health (Wulandari et al., 2020). The information given in the form of socialization was also carried out during the introduction of Standard Operating Procedures (SOPs) that have been developed in this community service. Technically, this program was conducted in Laweyan Hotel. 
Vol. 2, No. 2, December 2021

2. Focus Group Discussion.

This activity was conducted by the community service team and hotel management to develop Standard Operating Procedures (SOPs) for Hotel Laweyan. The Focus Group Discussion (FGD) was also done to develop standard operating procedures (SOPs). Furthermore, all stages might possibly be observed under the following figure 2.

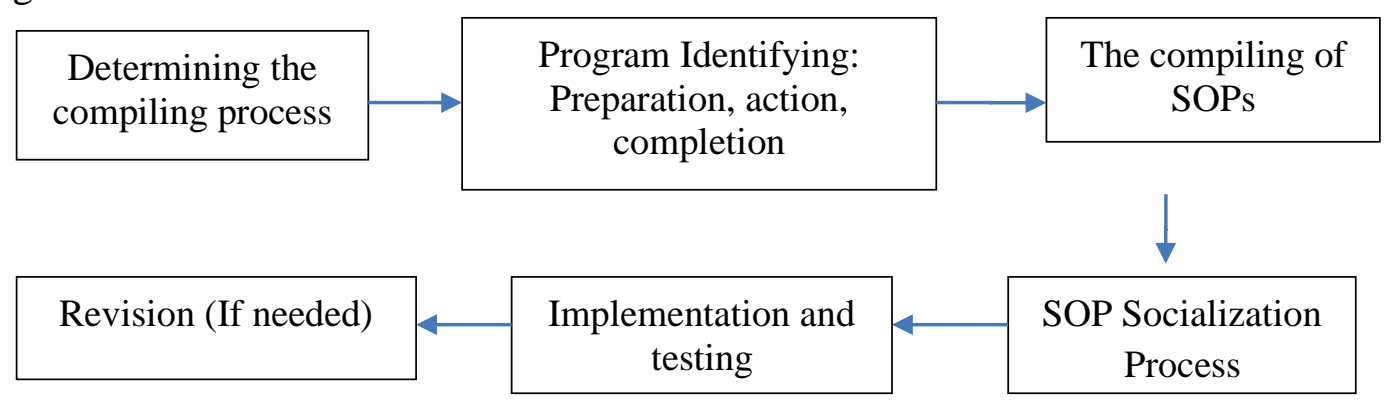

Figure 2. Stages in Compiling the Standard Operating Procedure (SOP)

\section{Testing}

At this step, the SOPs that had previously been developed were tested for implementation. This step was done together with socialization or introductory stage of the SOP to the community such as guests before staying at the hotel. They were all participating in implementing health protocols required by the government. In short, this program was implemented at the Laweyan hotel in during June 2020.

\section{RESULTS AND DISCUSSION}

This community service was done for a month since June 2020. Some stages were done in sequence during this community service program as listed below:

1. Socialization

The introductory stage was done only in a single day on June 9, 2020. The community service team, in collaboration with doctors from dr. Muwardi Hospital, paid a visit to the Laweyan Hotel. The team held an introductory program about the dangers of Covid-19 as well as the ways to prevent it. On that occasion, the Doctor explained to the management and employees of Hotel Laweyan as many as 7 (seven) participants regarding 1) Coronavirus Disease (Covid 19) and its transmission. 2) People who need to be monitored (People from infected areas). 3) Self and others' prevention such as washing hands, wearing masks, keeping a distance. The socialization was carried out in all points of the hotel from the reception points, room cleanliness, kitchen, and hotel management. The team of was then divided into two groups. The first group of 3 (three) people is in charge of preparing all the complete documents for PKM and collaboration with the Hospital. The second team of 2 (two) people is in charge to compile SOP documents, socializing SOPs, and ensuring implementation trials (Saputra et al., 2020). Furthermore, the socialization of covid-19 prevention and the need for documents that are used as work steps for its implementation can be seen in Figures 2 and Figure 3. 
SPEKTA

Jurnal Pengabdian Kepada Masyarakat : Teknologi dan Aplikasi

Vol. 2, No. 2, December 2021

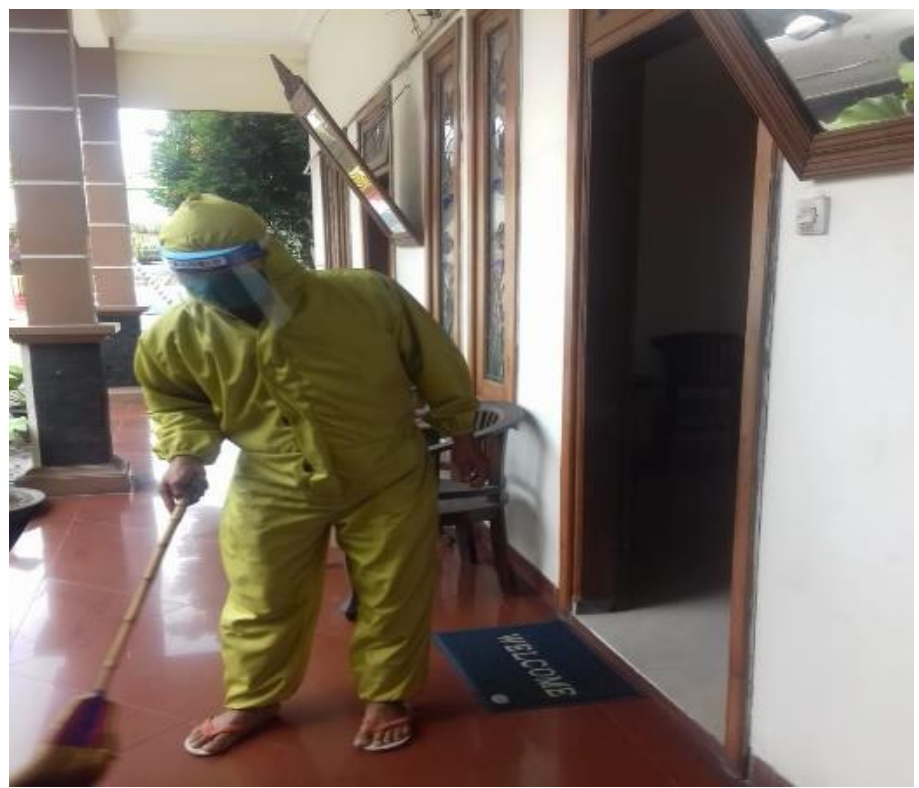

Figure 3. Room cleaning demonstration in the outdoor

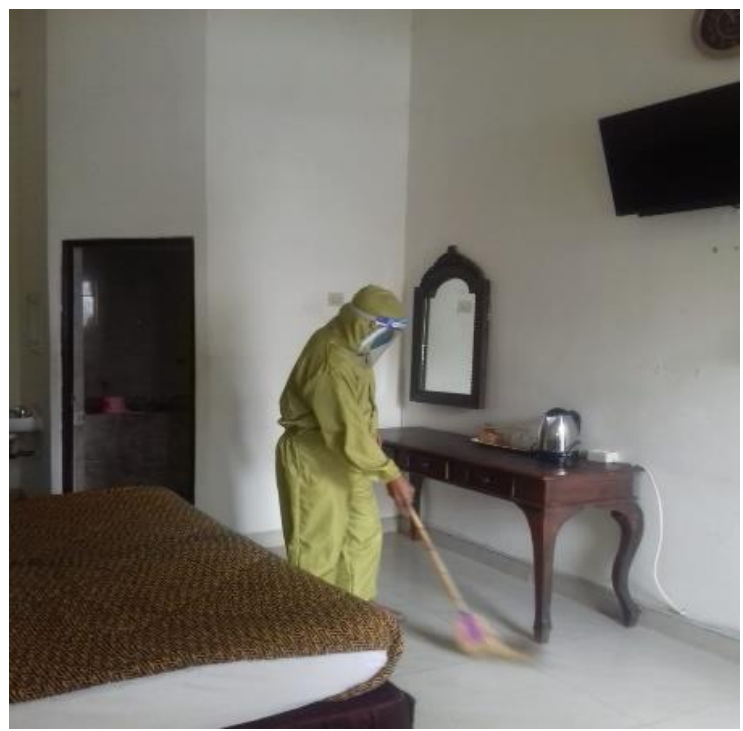

Figure 4. Room cleaning demonstration in the indoor

At the same time, health protocols are also demonstrated for guests who will come and visit hotel environment. Figures 5 and figure 6 show the health protocol that was implemented at Laweyan Hotel. 
Vol. 2, No. 2, December 2021

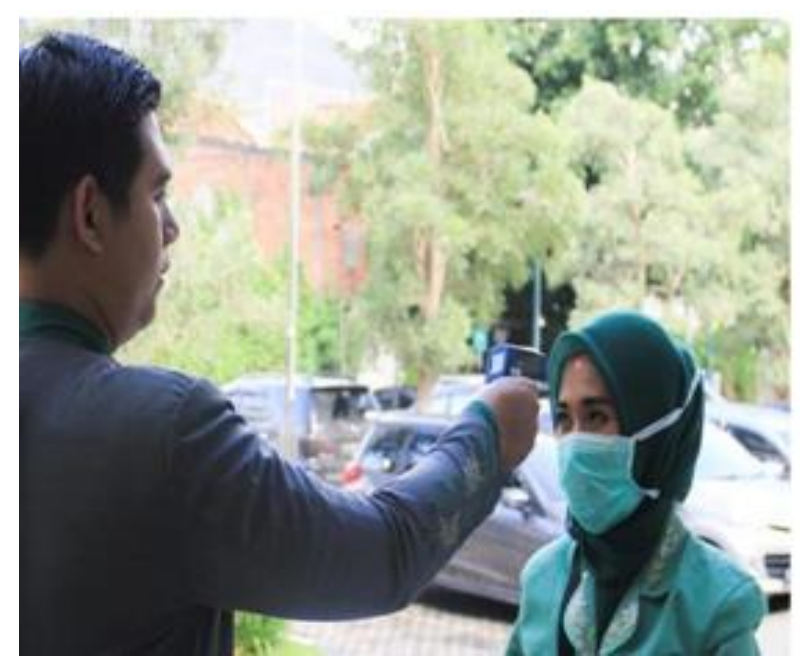

Figure 5. Body Temperature Detection

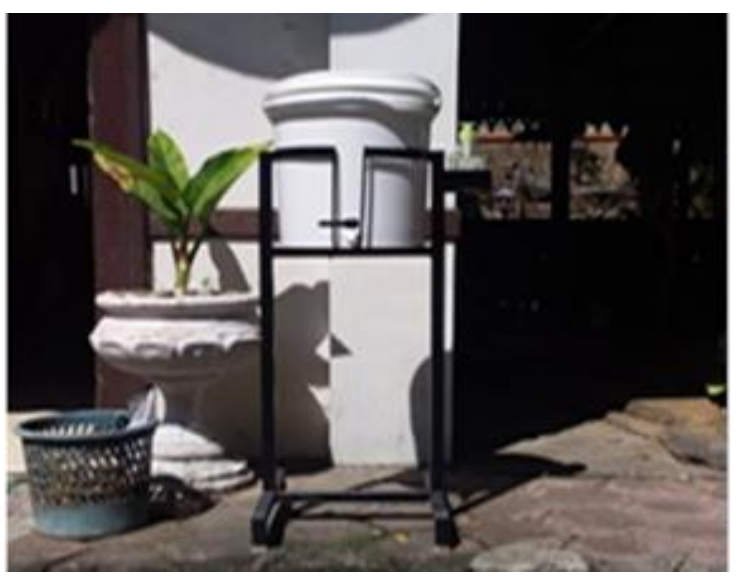

Figure 6. Hand Washing Point

2. Focus Discussion Group (FGD)

The Focus Group Discussion (FGD) was held on 17 and 18 June 2020. This program was attended by the community service team. In the event, representatives from the Indonesian Hotel and Restaurant Association (PHRI), Pontanius Kuswiyata., SE., M.Par. as well as the manager of Hotel Laweyan were also joining the program. Besides, the representative of the hotel employees, Mr. Suprapto, also participated in the focus group discussion. The program was taken to formulate a standard operating procedure (SOP) to mitigate the Covid-19 outbreak. In detail, Figures 7 show the atmosphere of the program. Previously, the speaker delivered the introductory understanding towards Covid-19. She also explained the role of SOPs for the tourism industry that must be well-understood in the government sector (Junita, 2017). Then after that, a discussion was specially programmed to design the related SOPs. As the result, the SOPs concern on the Front Office and House Keeping were designed at the time. 
Vol. 2, No. 2, December 2021
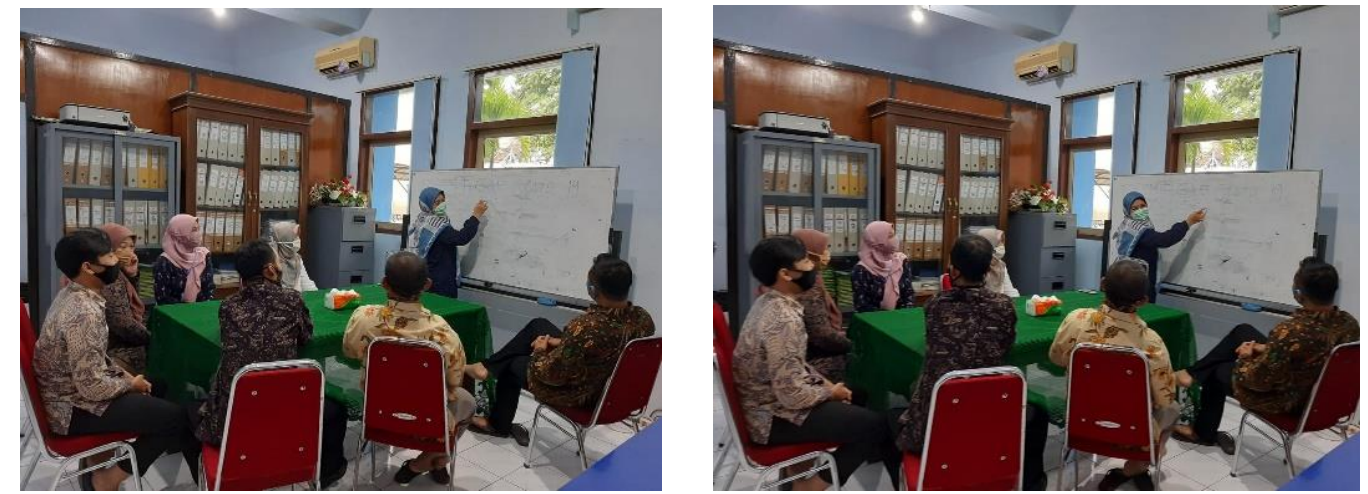

Figure 7. FGD Process

3. Testing and trials

On June 22, 2020, Mr. Pontianus Kuswiyata as hotel manager received aid with a set of tools for handwashing to put in front of the entrance gate. Furthermore, this might be previously seen in Figures 5 and 6 . In addition, hotel management also received personal protective equipment in the form of hazelnut clothes, masks, and gloves. This is figured out under Figure 8.

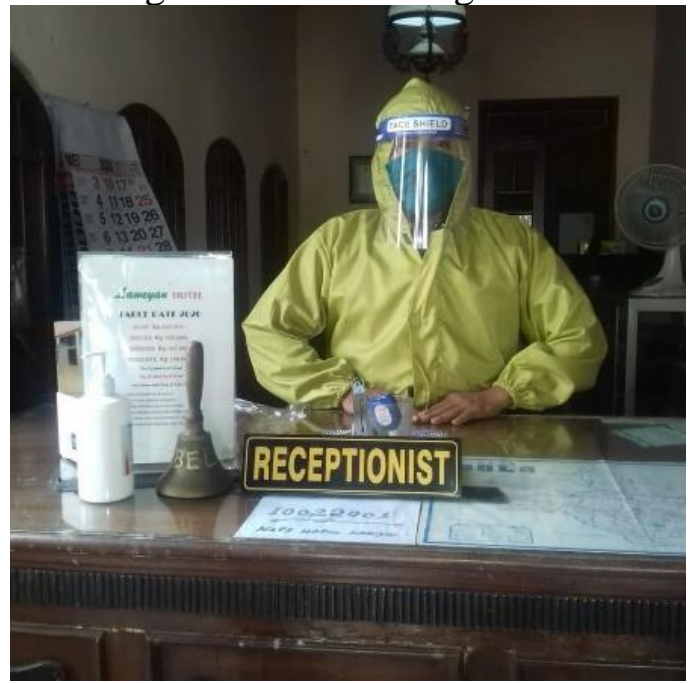

Figure 8. A set of personal protective equipment support from PKM team

At the same time, the hotel management also received the Front Office and House Keeping SOPs. In addition, there is also an additional statement of rules to be tested on guests and employees. The picture below is an SOP that has been piloted at the Laweyan Hotel, Surakarta. This aims to drive people's behavior to start a healthy life and make efforts to prevent disease as well as to reduce the spread of the virus (Wonok, Wowor, and Tucunan, 2020). SOPs implementation will cause several challenges in various sectors, both individually and the company (Stiyawan, Mansur and Noor, 2018). 
SPEKTA

Jurnal Pengabdian Kepada Masyarakat : Teknologi dan Aplikasi

Vol. 2, No. 2, December 2021

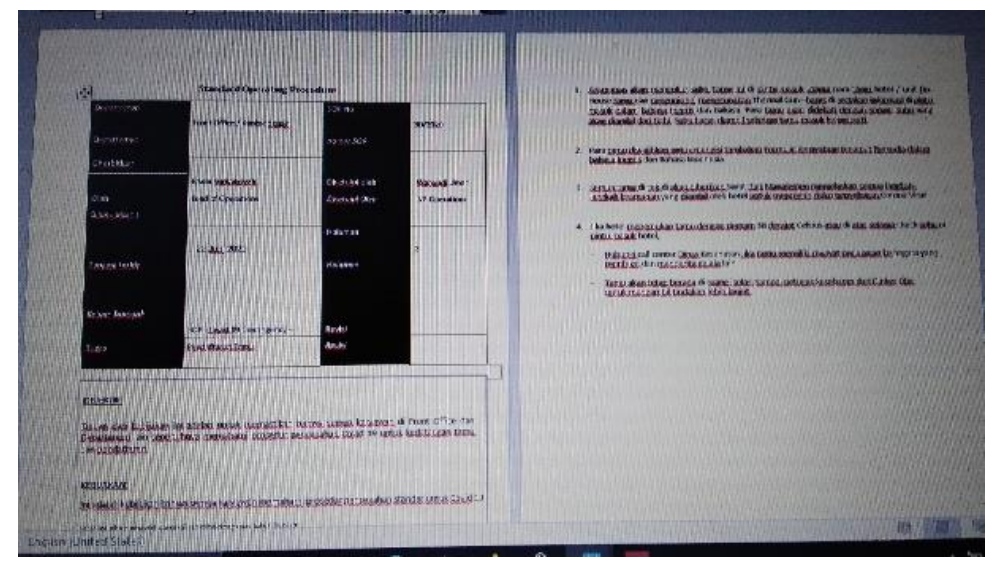

Figure 9. Front Office SOP

\section{CONCLUSION}

As a result of the implemented program, it might be briefly concluded that SOPs is prominently required for disaster mitigation even though it is only part of a formal administrative papers. Once needed, the hotel does not have the prerogative to handle it in a correct and quick way. In addition, the existing human resources must also be prepared to anticipate unpredictable things, especially when it drives to the safety and health of consumers. On the other hand, SOPs can also be used as special section to improve employee performance. This is due to the steps to be taken are supposed to be clearly defined. However, there are still many problems in the hotel or guesthouse industry. Therefore, socialization and more serious handling are much needed. Unfortunately, this kind of problem cannot be solved in the short term because it all depends on human behavior itself. In addition, the impact of being not complying with SOPs implementation will cause several challenges in various sectors, both individually and the company. Besides, other impacts will also appear following the performance outcomes.

\section{REFERENCES}

Aida, N. R. (2020, Maret 19). Update Virus Corona di Dunia: 214.894 Orang Terinfeksi, 83.313 Sembuh, 8.732 Meninggal Dunia. Kompas.com. Diunduh dari https://www.kompas.com/tren/read/2020/03/19/081633265/update-virus-coronadi-dunia-214894-orang-terinfeksi-83313-sembuh-8732.

Buana, R. D. (2017) 'Analisis Perilaku Masyarakat Indonesia dalam Menghadapi Pandemi Covid-19 dan Kiat Menjaga Kesejahteraan Jiwa', Sosial dan Budaya, Fakultas Syariah dan Hukum Universitas Islam Negeri (UIN) Syarif Hidayatullah Jakarta, 53(9), pp. 1689-1699.

Buchori (2019) 'Pengaruh Standar Operasional Prosedur (Sop) Kerja Terhadap Peningkatan Kinerja Karyawan Pt. Indomobil Finance Lampung Timur', Jurnal DINAMIKA, 5(2), pp. 142-162.

Budiansyah, Arif (2020, Maret 16). Apa Itu Virus Corona dan Cirinya Menurut Situs WHO. Diunduh dari https://www.cnbcindonesia.com/tech/20200316135138-37145175/apa-itu-virus-corona-dan-cirinya-menurut-situs-who.

Fitri, A. M., Nurcandra, F. and Pristya, T. Y. R. (2020) 'Pelatihan Upaya Kesehatan Kerja Bagi Masyarakat Cipayung Kota Depok', Dinamisia : Jurnal Pengabdian Kepada Masyarakat, 4(4), pp. 605-610. 
Vol. 2, No. 2, December 2021

Junita, T. D. (2017) 'Peranan Sop Pada Organisasi Pemerintahan Kota Surabaya Dalam Peningkatan Kepuasan Pelayanan Kepada Masyarakat (Studi Di Bagian Umum dan Protokol Pemerintahan Kota Surabaya)', JPAP: Jurnal Penelitian Administrasi Publik, 3(2), pp. 858-863.

Kiswantoro, A., Rohman, H. and Susanto, D. R. (2020) 'Penyaluran Alat Pencegahan dan Sosialisasi Protokoler Kesehatan untuk Pelayanan Kunjungan Wisatawan dalam Menghadapi New Normal Pasca Pandemi Covid-19', Jurnal Abdimas Pariwisata.

Kurniawan, B. and Jayanti, S. (2016) 'Analisis Kepatuhan Pelaksanaan Standard Operational Procedure (Sop) Pada Pekerja Kelistrikan Di Pt. Angkasa Pura I Semarang Tahun 2016', Jurnal Kesehatan Masyarakat (e-Journal), 4(3), pp. 537548.

Lina Dewi Anggraeni, E. I. D. (2020) 'Optimalisasi Perilaku Hidup Bersih dan Sehat Menuju Adaptasi Kebiasaan Baru', Jurnal Kreativitas Pengabdian Kepada Masyarakat (PKM).

Pinontoan, M., Dengo, S. and Ruru, J. (2015) 'Implementasi Standar Operasional Prosedur Dalam Pelayanan Bpjs Kesehatan Di Rsu Prof. Dr. Kandou Manado', Jurnal Administrasi Publik UNSRAT, 3(031), p. 1386.

Saputra, M. et al. (2020) 'Evaluasi Pedoman Penanganan Cepat Medis dan Kesehatan Masyarakat tentang Coronavirus Disease (COVID-19) di Indonesia', Jurnal Ilmiah Ilmu Keperawatan Indonesia.

Stiyawan, H., Mansur, M. and Noor, V. M. M. (2018) 'Dampak Tidak Patuh Terhadap Pelaksanaan SOP Alur Rawat Jalan di Rumah Sakit "X" Malang', Ekspektra: Jurnal Bisnis dan Manajemen, 2(1), p. 01.

Windu, F. F. (2017) 'Pembuatan Standard Operating Procedure (SOP) Layanan Perpustakaan PT. Semen Padang', Jurnal Ilmu Informasi Perpustakaan dan Kearsipan, 6(1), pp. 170-178.

Wonok, M. J., Wowor, R. and Tucunan, A. A. T. (2020) 'Gambaran Perilaku Masyarakat Tentang Pencegahan Covid-19 Di Desa Tumani Kecamatan Maesan Kabupaten Minahasa Selatan', Jurnal KESMAS.

Wulandari, A. et al. (2020) 'Hubungan Karakteristik Individu dengan Pengetahuan tentang Pencegahan Coronavirus Disease 2019 pada Masyarakat di Kalimantan Selatan', Jurnal Kesehatan Masyarakat Indonesia. 
SPEKTA

Jurnal Pengabdian Kepada Masyarakat : Teknologi dan Aplikasi

Vol. 2, No. 2, December 2021

This page is intentionally left blank. 